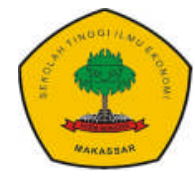

JURNAL ORGANISASI DAN MANAJEMEN

Issue 1 (Agustus, 2019)

https://doi.org/10.31227/osf.io/gcda8

\title{
Pengaruh Kompensasi dan Motivasi Terhadap Kepuasan Kerja Pegawai
}

\author{
1) Muhammad Yusrizal Syahrir Firdaus \& ${ }^{2)}$ Herman Sjahruddin \\ yusrizal453@gmail.com
}

1) Mahasiswa Program Studi Manajemen pada Sekolah Tinggi Ilmu Ekonomi Bongaya Makassar

2) Dosen Program Studi Manajemen pada Sekolah Tinggi Ilmu Ekonomi Bongaya Makassar

\begin{abstract}
ABSTRAK
Penelitian ini bertujuan untuk menguji dan menganalisis pengaruh kompensasi dan motivasi terhadap kepuasan kerja pegawai. Pendekatan penelitian ini adalah kuantitatif. Populasi dalam penelitian ini adalah keseluruhan pegawai yang bekerja pada Kantor Balai Diklat Keagamaan Kota Makassar. Sampel penelitian ini sebanyak 53 pegawai sebagai unit analisis. Hasil uji hipotesis dengan menggunakan analisis regresi linear berganda memberikan bukti bahwa pemberian kompensasi dan motivasi kerja yang ditunjukkan terbukti dapat meningkatkan kepuasan kerja pegawai. Motivasi kerja merupakan variabel yang dominan berpengaruh terhadap kepuasan kerja pegawai.
\end{abstract}

Kata kunci : $\quad$ Kompensasi, motivasi kerja, kepuasan kerja

\section{ABSTRACT}

Regression analysis is constructed for capturing the effect of compensation and work motivation on employee job satisfaction. The population in this study were all employees who worked at the Makassar City Education and Training Center Office. The sample of this study were 53 employees as a unit of analysis. The results of hypothesis testing using multiple linear regression analysis provide evidence that compensation and work motivation shown are proven to increase employee job satisfaction. Work motivation is the dominant variable affecting employee job satisfaction.

Keywords: Compensation, work motivation, employee job satusfaction 


\section{JURNAL ORGANISASI DAN MANAJEMEN}

Issue 1 (Agustus, 2019)

\section{https://doi.org/10.31227/osf.io/gcda8}

\section{A. Latar Belakang}

Teori kepuasan kerja yang dikemukakan Hersberg (2000) dalam Sinollah (2011) menyatakan bahwa terdapat dua faktor penentu kepuasan kerja, yaitu; pertama, kebutuhan akan kesehatan atau kebutuhan akan pemeliharaan. Hal ini berhubungan dengan hakikat manusia yang ingin memperoleh ketentraman lahiriyah. Faktor-faktor pemeliharaan meliputi balas jasa, kondisi kerja fisik, kepastian pekerjaan, supervise yang menyenangkan, mobil dinas, rumah dinas, dan bermacam-macam tunjangan lainnya. Hilangnya faktor pemeliharaan ini dapat menyebabkan timbulnya ketidakpuasan dan tingkat absensi pegawai serta turnover akan meningkat. Faktor-faktor pemeliharaan ini perlu mendapat perhatian yang wajar dari pimpinan agar kepuasan dan kegairahan kerja karyawan dapat ditingkatkan. Kedua, faktor pemeliharaan ini menyangkut kebutuhan psikologi seseorang. Kebutuhan ini meliputi serangkaian kondisi instrinsik, kepuasan pekerjaan yang apabila terdapat dalam pekerjaan akan menggerakkan tingkat motivasi yang kuat yang dapat menghasilkan prestasi kerja yang baik. Jika kondisi ini tidak ada maka kondisi ini ternyata menimbulkan rasa ketidakpuasan yang berlebihan. Serangkaian faktor ni dinamakan satisfier atau motivators yang meliputi: Prestasi, Pengakuan, Pekerjaan itu sendiri, Tanggung jawab, Kemajuan dan Pengembangan potensi individu.

Salah satu faktor yang mendasari penciptaan kepuasan kerja ialah Kompensasi. Kompensasi adalah semua pendapatan yang berbentuk uang, barang langsung atau tidak langsung kepada pegawai sebagai imbalan atas jasa yang diberikan kepada instansi. Besar kecilnya kompensasi mencerminkan status, pengakuan, dan tingkat pemenuhan kebutuhan yang dinikmati oleh karyawan bersama keluarganya. Jika balas jasa yang diterimanya semakin tinggi, statusnya semakin baik, dan pemenuhan kebutuhan yang dinikimatinnya semakin banyak pula. Dengan demikian kepuasan kerjanya semakin baik (Hasibuan 2013 : 118).

Menurut Mutiara S. Panggabean dalam Subekhi dan Jauhar (2012:176) kompensasi adalah setiap bentuk penghargaan yang diberikan karyawan sebagai balas jasa atas kontribusi yang mereka berikan kepada organisasi". Pada umumnya kompensasi diberikan untuk menarik karyawan yang berkualitas, mendorong karyawan untuk berprestasi tinggi, dan mempertahan karyawan yang produktif dan berkualitas untuk memiliki loyalitas yang tinggi.

Selain kompensasi, motivasi kerja juga penting dalam penciptaan kepuasan kerja karena menurut Stokes dalam Kadarisman (2012:278) "motivasi kerja adalah sebagai pendorong bagi seseorang untuk melakukan pekerjaannya dengan baik, juga merupakan faktor yang membuat perbedaan antara sukses dan gagalnya dalam banyak hal dan merupakan tenaga emosional yang sangat penting untuk sesuatu pekerjaan baru.

Definisi diatas menunjukkan bahwa motivasi merupakan dorongan bagi sesorang pegawai agar mau bekerja dengan sungguh-sungguh guna mencapai tujuan pribadi pegawai tersebut sampai akhirnya pencapaian tujuan perusahaan. Oleh karena itu setiap orang mempunyai kebutuhan yang berbedabeda, maka diperlukan pemahaman kebutuhan umum yang selalu ada pada setiap orang. Hal ini dapat dilakukan karena pada dasarnya setiap orang

Halaman 2 
Issue 1 (Agustus, 2019)

https://doi.org/10.31227/osf.io/gcda8

mempunyai kebutuhan yang dominan. Dengan mengetahui kebutuhan apa yang mendominasi pekerjaannya, seorang pemilik atau manejer akan dapat memotivasi pekerjaannya dengan jalan memenuhi kebutuhan pekerja tersebut sehingga pekerja dapat bekerja secara maksimal.

Hasil penelitian Yusron Rozzaid dkk (2015) memberikan bukti bahwa kompensasi dan motivasi secara bersama berpengaruh terhadap kepuasan kerja karyawan, sedangkan secara parsial kedua variabel bebas yakni kompensasi dan motivasi berpengaruh terhadap kepuasan kerja. Adapun perbedaan hasil penelitian, ditunjukkan pada studi yang dilakukan Septian Adistyana Putra (2012) dapat diketahui bahwa faktor kompensasi berpengaruh terhadap kepuasan kerja tidak dapat diterima, sedangkan faktor motivasi berpengaruh terhadap kepuasan kerja dapat diterima.

\section{Tinjauan Teoritis}

\section{Kompensasi}

\section{a. Pengertian Kompensasi}

Menurut Kasmir (2016), kompensasi merupakan balas jasa yang diberikan perusahaan kepada karyawannya, baik yang bersifat keuangan maupun non keuangan. Artinya perusahaan akanmemberikan balas jasa kepada seluruh karyawan yang terlibat didalamnya. Balas jasa yang diberikan merupakan kewajiban perusahaan atas jerih payah yang diberikan kepada perusahaan selama bekerja. Kompensasi adalah hak karyawan atas beban dan tanggung jawab yang diberikan kepada perusahaan.Jadi kompensasi bagi perusaahan adalah sebagai kewajiban yang wajib diberikan, sedangkan bagi karyawan adalah hak yang harus diterimanya. Kemudian kompensasi dapat diberikan ada yang bersifat tetap dan bersifat tidak tetap. Tetap artinya kompensasi akan dibayar kepada karyawan, seperti gaji dan tunjangan secara bulanan. Sedangkan tidak tetap adalah kompensasi diberikan tergantung dari prestasi kerjanya atau dengan pertimbangan lain.

\section{b. Jenis Kompensasi}

1) Kompensasi Finansial, kompensasi yang diterima dalam bentuk financial dengan sistem pembayaran secara langsung (direct payment) dan pembayaran tidak langsung (indirect payment).

a. Kompensasi langsung, kompensasi langsung berupa gaji pokok seperti upah, gaji, dan kompensasi variabel seperti insentif dan bonus.

b. Kompensasi tidak langsung, kompensasi tidak langsung berupa dalam bentuk tunjangan seperti asuransi, liburan, atas biaya perusahaan, dan dana pensiun.

2) Kompensasi NonFinansial, kompensasi nonfinansial merupakan yang berkaitan dengan kepuasan kerja yang diterima pekerja. Pembayaran kompensasi nonfinansial diberikan dalam bentuk penghargaanpenghargaan seperti pekerjaan yang lebih menantang, jam kerja yang 


\section{JURNAL ORGANISASI DAN MANAJEMEN}

Issue 1 (Agustus, 2019)

https://doi.org/10.31227/osf.io/gcda8

lebih luas, dan kantor yang lebih bergengsi. Aspek kompensasi nonfinansial mencakup faktor-faktor psikologis dengan fisik dalam lingkungan organisasinya.

\section{c. Indikator Kompensasi}

Indikator dari kompensasi menurut Hasibuan (2012) adalah sebagai berikut; (1) Gaji; (2) Insentif; (3) Fasilitas Kantor dan (4) Tunjangan.

\section{Motivasi}

\section{a. Pengertian Motivasi}

Dalam kehidupan berorganisasi, pemberian dorongan sebagai bentuk motivasi kerja kepada bawahan penting dilakukan untuk meningkatkan prestasi karyawan. Menurut Hasibuan (2014), motivasi berasal dari kata lain movere yang berarti dorongan atau pemberian daya penggerak yang menciptakan kegairahan kerja seseorang agar mereka mau bekerja sama, bekerja efektif, dan terintgerasi dengan segala daya upayanya untuk mencapai kepuasan.

Menurut Wursanto (2004) dalam Yensy (2010) mengatakan bahwa motivasi adalah alasan-alasan, dorongan-dorongan yang ada di dalam diri manusia yang menyebabkan ia melakukan sesuatu atau perbuatan sesuatu.

b. Jenis-jenis Motivasi

Menurut Nawawi dalam Arindha (2014) membagi motivasi berdasarkan sumbernya, yaitu: motivasi instrinsik dan motivasi ekstrinsik.

\section{c. Indikator Motivasi}

Indikator-indikator untuk mengukur motivasi kerja menurut Syahyuti (2010), yaitu; (1) Dorongan mencapai tujuan, (2) Semangat kerja, (3) Inisiatif dan kreatifitas dan (4) Rasa Tanggung Jawab

\section{Kepuasan kerja}

\section{a. Pengertian kepuasan kerja}

Kepuasan kerja adalah tingkat kesenangan yang dirasakan oleh seseorang atas peranan atau pekerjaannya dalam organisasi.Kepuasan kerja adalah tingkat rasa puas individu bahwa mereka dapat imbalan yang setimpal dari bermacam-macam aspek situasi pekerjaan dari organisasi tempat mereka bekerja. Jadi kepuasan kerja menyangkut psikologis individu didalam organisasi, yang diakibatkan oleh keadaan yang ia resakan dari lingkungannya. Kepuasan kerja merupakan suatu perasaan yang menyokong atau tidak menyokong diri pegawai yang berhubungan dengan pekerjaannya maupun dengan kondisi dirinya (Sinambela,2012).

b. Indikator Kepuasan Kerja

Melayu S.P Hasibuan (2008), menyatakan bahwa kepuasan kerja adalah sikap emosinal yang menyenangkan dan mencintai pekerjaanya, sikap ini dicerminkan oleh moral kerja, kedisplinan, dan prestasi kerja, indikator kepuasan kerja adalah; (1) Menyenangi pekerjaannya, (2) Mencintai pekerjaannya, (3) moral kerja, dan disiplin kerja 
Issue 1 (Agustus, 2019)

https://doi.org/10.31227/osf.io/gcda8

\section{Penelitian terdahulu}

Penelitian terdahulu yang menjadi referensi dalam penelitian ini adalah sebagai berikut :

Tabel 1 Penelitian Terdahulu

\begin{tabular}{|c|c|c|c|}
\hline $\begin{array}{l}\text { Nama, Tahun dan Judul } \\
\text { Penelitian }\end{array}$ & $\begin{array}{l}\text { Variabel dan Tujuan } \\
\text { Penelitian }\end{array}$ & $\begin{array}{c}\text { Populasi, Sampel dan } \\
\text { Alat Analisis }\end{array}$ & Hasil Penelitian \\
\hline $\begin{array}{l}\text { Yusron rozzaid, Toni } \\
\text { Herlambang, Anggun } \\
\text { Meyrista Devi (2015) } \\
\text { Pengaruh Kompensasi } \\
\begin{array}{l}\text { dan Motivasi } \\
\text { Kepuasan }\end{array} \\
\text { Karyawan } \\
\text { nusapro Kerja } \\
\text { Persada telemedia } \\
\text { Banyuwangi. }\end{array}$ & $\begin{array}{l}\text { 1. Kompensasi } \\
\text { 2. Motivasi } \\
\text { 3. Kepuasan Kerja } \\
\text { Tujuan Penelitian ini } \\
\text { adalah untuk } \\
\text { menganalisis } \\
\text { pengaruh kompensasi } \\
\text { dan motivasi secara } \\
\text { bersama ataupun } \\
\text { parsial terhadap } \\
\text { kepuasan kerja } \\
\text { karyawan }\end{array}$ & $\begin{array}{l}\text { Penelitian ini } \\
\text { menggunakan seluruh } \\
\text { populasi dan sekaligus } \\
\text { dijadikan sampel sebagai } \\
\text { subyek penelitian yang } \\
\text { berjumlah 31 karyawan. } \\
\text { Analisis regresi linear } \\
\text { berganda. }\end{array}$ & $\begin{array}{l}\text { Kompensasi dan } \\
\text { motivasi secara } \\
\text { bersama } \\
\text { berpengaruh } \\
\text { pada kepuasan } \\
\text { kerja karyawan. }\end{array}$ \\
\hline $\begin{array}{l}\text { Ni made Nurcahyani, } \\
\text { I.G.A. Dewi Adnyani } \\
\text { (2016) } \\
\text { Pengaruh Kompensasi } \\
\text { dan Motivasi Terhadap } \\
\text { Kinerja karyawan } \\
\text { dengan kepuasan kerja } \\
\text { sebagai variabel } \\
\text { intervening } \\
\text { pada PT. Sinar Sosro } \\
\text { Pabrik Bali. }\end{array}$ & $\begin{array}{l}\text { 1. Kompensasi } \\
\text { 2. Motivasi } \\
\text { 3. Kinerja } \\
\text { 4. Kepuasan Kerja } \\
\text { Penelitian ini } \\
\text { bertujuan untuk } \\
\text { mengetahui pengaruh } \\
\text { kompensasi, motivasi. } \\
\text { kompensasi terhadap } \\
\text { kinerja karyawan, } \\
\text { dengan kepuasan } \\
\text { kerja sebagai variabel } \\
\text { intervening }\end{array}$ & $\begin{array}{l}\text { Populasi dalam } \\
\text { penelitian berjumlah } \\
116 \text { orang. Penelitian ini } \\
\text { menggunakan sampel } \\
\text { jenuh dengan } \\
\text { menggunakan seluruh } \\
\text { karyawan. } \\
\text { Penelitian ini } \\
\text { menggunakan teknik } \\
\text { analisis data yaitu } \\
\text { analisis jalur (path } \\
\text { analysis). }\end{array}$ & $\begin{array}{l}\text { Kompensasi dan } \\
\text { motivasi } \\
\text { berpengaruh } \\
\text { positif dan } \\
\text { signifikan } \\
\text { terhadap kinerja } \\
\text { dan kepuasan } \\
\text { kerja memediasi } \\
\text { berpengaruh } \\
\text { kompensasi dan } \\
\text { motivasi } \\
\text { berpengaruh } \\
\text { terhadap kinerja. }\end{array}$ \\
\hline $\begin{array}{l}\text { Septian Adistyana Putra } \\
(2012) \\
\text { Pengaruh Kompensasi } \\
\text { dan Motivasi Terhadap } \\
\text { kepuasan kerja } \\
\text { Karyawan }\end{array}$ & $\begin{array}{l}\text { 1. Kompensasi } \\
\text { 2. Motivasi } \\
\text { 3. Kepuasan Kerja } \\
\text { Tujuan dari penelitian } \\
\text { ini untuk } \\
\text { membuktikan } \\
\text { pengaruh positif } \\
\text { antara hubungan } \\
\text { kompensasi, motivasi } \\
\text { dan kepuasan kerja } \\
\text { pada karyawan PT } \\
\text { Borwita Citra Prima di } \\
\text { Sidoarjo. }\end{array}$ & $\begin{array}{l}\text { Teknik pengambilan } \\
\text { samplenya } \\
\text { menggunakan simple } \\
\text { random sampling yaitu } \\
\text { dimana semua anggota } \\
\text { populasi mempunyai } \\
\text { kesempatan yang sama } \\
\text { besar untuk dijadikan } \\
\text { sample penelitian. } \\
\text { Teknik analisis yang } \\
\text { digunakan dalam } \\
\text { penelitian ini adalah } \\
\text { SEM }\end{array}$ & $\begin{array}{l}\text { Faktor } \\
\text { kompensasi } \\
\text { berpengaruh } \\
\text { terhadap } \\
\text { kepuasan kerja } \\
\text { tidak dapat } \\
\text { diterima, } \\
\text { sedangkan faktor } \\
\text { motivasi } \\
\text { berpengaruh } \\
\text { terhadap } \\
\text { kepuasan kerja } \\
\text { dapat diterima. }\end{array}$ \\
\hline
\end{tabular}

Hasil review jurnal (2019)

\section{Metode Penelitian}

\section{A. Pendekatan Penelitian}

Dalam suatu penelitian sangat perlu dilakukan pendekatan penelitian, agar peneltian yang dilakukan dapat berjalan dengan baik dan sistematis.Pendekatan penelitian ini menggunakan pendekatan kuantitaif. Pendekatan kuantitatif adalah metode penelitian yang digunakan untuk 


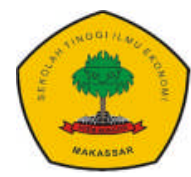

\section{JURNAL ORGANISASI DAN MANAJEMEN}

Issue 1 (Agustus, 2019)

https://doi.org/10.31227/osf.io/gcda8

meneliti populasi atau sampel tertentu yang bertujuan untuk menguji hipotesis yang telah ditetapkan (Sugiyono, 2013:13).

\section{B. Tempat dan Waktu Penelitian}

Penelitian ini dilakukan pada Kantor Balai Diklat Keagamaan Makassar yang beralamat Jl. Sultan Alauddin Kota Makassar. Penelitian ini berlangsung selama bulan februari 2019 sampai mei 2019.

\section{Populasi dan Sampel}

\section{Populasi}

Populasi adalah wilayah generalisasi yang terdiri atas objek/subyek yang mempunyai kualitas karakteristik tertentu yang ditetapkan oleh peneliti untuk mempelajari dan kemudia ditarik kesimpulannya (Sugiyono, 2010:115). Berdasarkan pernyataan tersebut, populasi dari penelitian ini adalah pegawai Kantor Balai Diklat Keagamaan Makassar sebanyak 53 pegawai.

\section{Sampel}

Penelitian ini menggunakan sampel jenuh, dimana Sampel Jenuh adalah teknik penentuan sampel bila semua anggota populasi digunakan sebagai sampel (Sugiyono, 2011:68). Sehingga jumlah sampel yang digunakan sama dengan jumlah populasi dalam penelitian ini, yaitu sebanyak 53 pegawai.

\section{Skala Pengukuran Variabel}

Skala yang digunakan dalam peneltian ini menggunakan skala ordinal dengan tipe skala likert, skala ini digunakan untuk mengukur sikap, pendapat dan persepsi seseorang atau sekelompok tentang sesuatu hal (Sugiyono 2010). Setiap pertanyaan dari variabel yang dalam kuesioner dengan mengacu pada skala likert, dimana masing-masing dibuat dengan menggunakan skala 1-5 ketegori jawaban, yang masing-masing jawaban diberi score atau bobotnya yaitu banyaknya score antara 1 sampai 5 yang dimulai dengan Sangat Tidak Setuju (STS) dengan Skor 1 sampai dengan Sangat Setuju (SS) dengan Skor 5

\section{E. Metode Analisis}

1) Analisis Statistik Deskriptif, analisis statistic deskriptif adalah statistik yang digunakan untuk menganalisis data dengan cara mendeskripsikan atau menggambarkan data yang telah terkumpul sebagaimana adanya tanpa bermaksud membuat kesimpulan yang berlaku umum atau generalisis (Sugiyono, 2014:147).

2) Analisis Statistik Inferensial, analisis statistik inferensial adalah teknik statistik yang digunakan untuk menganalisis data sampel dan hasilnya diberlakukan untuk populasi, statistik ini akan cocok digunakan bila sampe diambil dari populasi yang jelas dan teknik pengambilan sampel dari populasi itu dilakukan secara random (Sugiyono,2014). Adapun pada penelitian ini, peneliti menggunakan analisis regresi linear berganda bertujuan untuk mempelajari hubungan antara variabel yaitu hubungan antara variabel independen $(\mathrm{X})$ dengan variabel dependen $(\mathrm{Y})$. Analisis ini digunakan untuk mengetahui variabel dependen apakah positif atau 


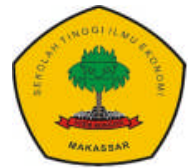

Issue 1 (Agustus, 2019)

https://doi.org/10.31227/osf.io/gcda8

negatif dan untuk memprediksikan nilai dari variabel dependen apabila nilai variabel dependen mengalami penaikan atau kenaikan persamaan regresi linear berganda (Ghozali,2011) adalah sebagai berikut:

$$
\begin{aligned}
& \mathrm{Y}=\alpha+\beta_{1}+\beta_{2} \mathrm{X}_{2}+\mathrm{e} \\
& \text { Keterangan: } \\
& \mathrm{Y}=\text { Kepuasan Kerja } \\
& \mathrm{X}_{1} \text { : Kompensasi } \\
& \mathrm{X}_{2} \text { : Motivasi } \\
& \alpha: \text { Konstanta } \\
& \beta \text { : Koefisien Regresi } \\
& \mathrm{e}: \text { Standar eror }
\end{aligned}
$$

\section{Hasil Penelitian}

\section{A. Identitas Responden}

Responden dalam penelitian adalah pegawai kantor Balai Diklat Kegamaan Makassar yang berjumlah 53 orang. Adapun identitas responden dapat dilihat dari table dibawah ini :

Tabel 2 Deskripsi Responden

\begin{tabular}{|c|c|c|}
\hline Deskripsi Responden & Frekuensi & Persentase \\
\hline Laki-Laki & 28 & 52.8 \\
\hline Perempuan & 25 & 47.2 \\
\hline Total Berdasarkan gender & 53 & 100 \\
\hline$<5$ Tahun & 4 & 7.5 \\
\hline$<10$ Tahun & 6 & 11.3 \\
\hline$<15$ Tahun & 9 & 17 \\
\hline$<20$ Tahun & 9 & 17 \\
\hline$>20$ Tahun & 25 & 47.2 \\
\hline Total berdasarkan Lama bekerja & 53 & 100 \\
\hline Sarjana & 9 & 69.8 \\
\hline Magister & 37 & 13.2 \\
\hline Doktor & 7 & 100 \\
\hline Total berdasarkan Pendidikan & 53 & \\
\hline
\end{tabular}

\section{B. Uji Instrumen}

1) Uji Validitas, berdasarkan dari hasil pengolahan data bahwa semua indikator dari variabel kompensasi, motivasi kerja dan Kepuasan Kerja mempunyai nilai correlation $>0.30$ dan signifikan $<0.05$ sehingga dengan demikian dapat dikatakan bahwa semua indikator dari kepuasan kerja yang dipergunakan dalam penelitian ini memiliki validitas yang layak dan signifikan.

2) Uji Reabilitas, berdasarkan hasil pengujian menunjukkan bahwa angkaangka dari nilai cronbach's alpha pada variabel kompensasi, motivasi dan 


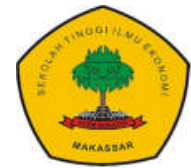

Issue 1 (Agustus, 2019)

https://doi.org/10.31227/osf.io/gcda8

kepuasan kerja dalam penelitian ini, semuanya menunjukkan besaran diatas nilai 0.60. Hal ini berarti bahwa seluruh penyataan untuk variabel kompensasi, motivasi dan kepuasan kerja adalah realible dan dapat disimpulkan bahwa instrument penyataan kuesioner menunjukkan keandalan dalam mengukur variabel-variabel dan telah memenuhi standar reabilitas dalam model penelitian.

\section{Uji Asumsi Klasik}

1) Uji Normalitas

\section{Tabel 3. Uji KS}

One-Sample Kolmogorov-Smirnov Test

\begin{tabular}{|ll|r|}
\hline & & \multicolumn{2}{|c|}{ Unstandardized Residual } \\
\hline $\mathrm{N}$ & & 53 \\
Normal Parameters ${ }^{\mathrm{a}, \mathrm{b}}$ & Mean & 0 \\
& Std. Deviation & 0.237025 \\
& Absolute & 0.101 \\
Most Extreme Differences & Positive & 0.101 \\
& Negative & -0.089 \\
Kolmogorov-Smirnov Z & & 0.739 \\
Asymp. Sig. (2-tailed) & & 0.646 \\
\hline
\end{tabular}

a. Test distribution is Normal.

b. Calculated from data.

Berdasarkan hasil pengolahan data bahwa menunjukkan nilai K-S yaitu $0.739>0.05$ serta nilai signifikansi yaitu $0.646>0.05$, maka dapat disimpulkan bahwa data dalam penelitian ini terdistribusi normal.

2) Uji Multikolineritas

Tabel 4 Hasil Uji Multikolineritas

\begin{tabular}{|r|l|r|r|}
\hline \multicolumn{2}{|c|}{ Model } & \multicolumn{2}{|c|}{ Collinearity Statistics } \\
\cline { 3 - 4 } \multicolumn{2}{|c|}{1} & Tolerance & \multicolumn{1}{c|}{ VIF } \\
\hline \multirow{2}{*}{1} & (Constant) & & \\
\cline { 2 - 4 } & Kompensasi & .364 & 2.745 \\
\cline { 2 - 4 } & Motivasi & .364 & 2.745 \\
\hline
\end{tabular}

Berdasarkan hasil pengolahan data bahwa untuk variabel kompensasi dengan nilai tolerance yaitu $0.364>0.10$ dan nilai VIF 2.745 $<10.00$, sedangkan untuk variabel motivasi dengan nilai tolerance 0.364 $>0.10$ dan nilai VIF $2.745<10.00$. Maka dapat di simpulkan bahwa model regresi linear tidak terjadi multikolinearitas.

3) Uji Autokorelasi

Tabel 5 Hasil Uji Autokorelasi

\begin{tabular}{|l|lr|}
\hline Model & \multicolumn{2}{|c|}{ Durbin-Watson } \\
\hline & 1 & \\
\hline
\end{tabular}

Authors : Firdaus \& Sjahruddin Issue 1 (Agustus, 2019); 01 15 


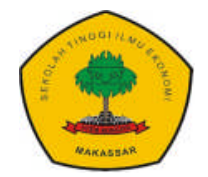

\section{JURNAL ORGANISASI DAN MANAJEMEN}

Issue 1 (Agustus, 2019)

https://doi.org/10.31227/osf.io/gcda8

Berdasarkan hasil pengolahan data melalui spss maka nilai durbinwatson ditunjukkan sebesar 1.570. untuk menunjukkan ada ataupun tidaknya autokorelasi maka dapat dijelaskan melalui $\mathrm{dL}=1.4797$ dan nilai $\mathrm{dU}=1.6359$, serta nilai $4-1.4797=1.4793$ sehingga dapat dijelaskan bahwa nilai DW lebih besar daripada ( $4-\mathrm{dL})$, maka koefisien autokorelasi lebih kecil daripada nol, berarti ada autokorelasi negative.

\section{4) Uji Heteroskedastisitas}

Berdasarkan hasil pengolahan data menunjukkan bahwa nilai signifikansi variabel Kompensasi (X1) sebesar 0.690 lebih besar dari 0.05 artinya tidak terjadi heteroskedastisitas yang berarti datanya homogen dan nilai signifikansi variabel Motivasi (X2) sebesar 0.259 lebih besar dari 0.05 artinya tidak terjadi heteroskedastisitas berarti datanya juga homogen. Dengan demikian dapat disimpulkan bahwa data ini memenuhi uji asumsi klasik pada uji heteroskedastisitas.

\section{5) Uji Linearitas}

\section{Gambar 1. Hasil Uji Linearitas variabel Kompensasi $\left(\mathrm{X}_{1}\right)$}

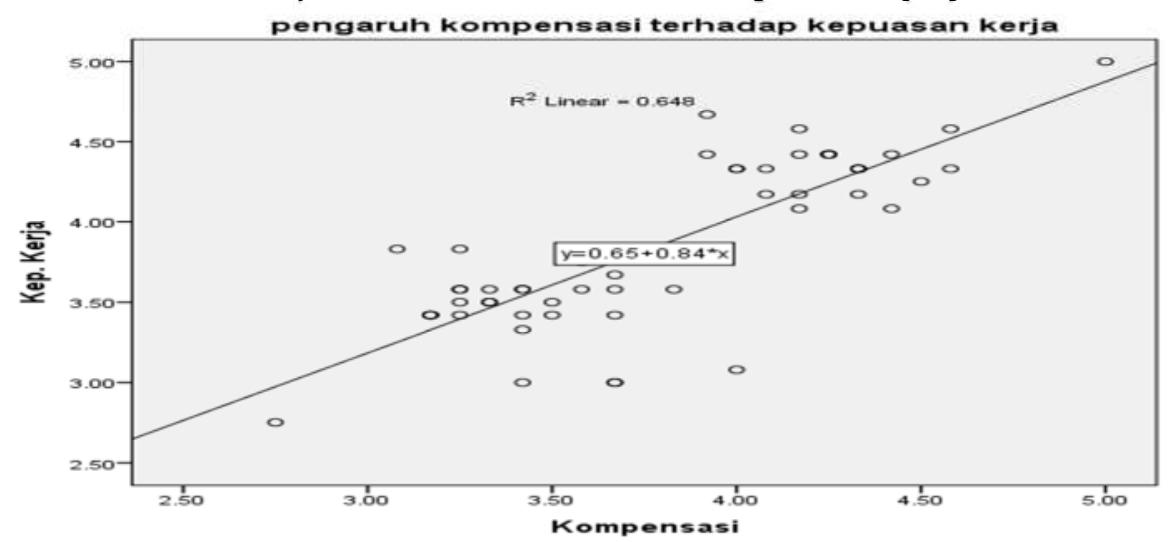

Berdasarkan gambar diatas menunjukkan bahwa terdapat hubungan yang searah (linear) antara kompensasi dengan kepuasan kerja, hal ini ditunjukkan dengan garis linearitas yang dimuncul pada gambar tersebut dengan nilai keofisien regresi linearitas sebesar 0.648 atau dengan tingkat linearitas sebesar $64.8 \%$.

\section{Gambar 2 Hasil Uji Linearitas variabel Motivasi $\left(\mathrm{X}_{2}\right)$}

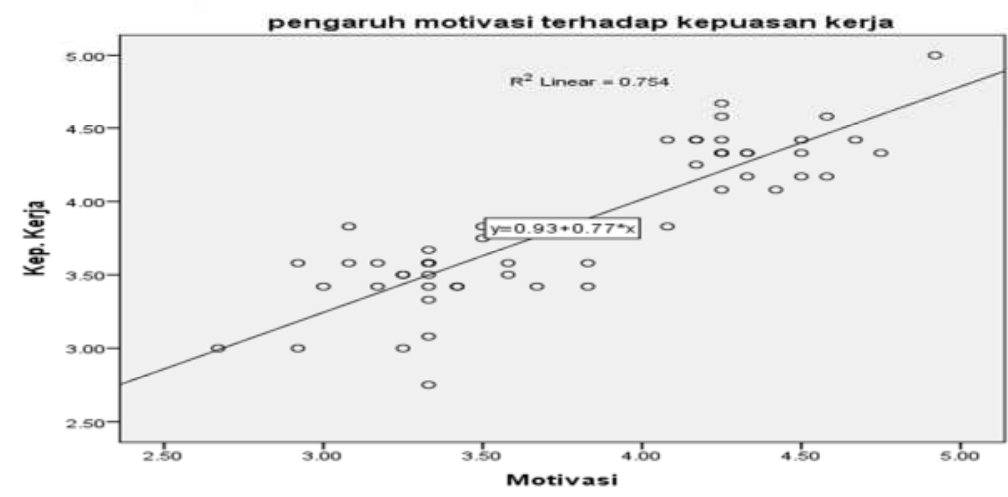

Halaman 9

Authors : Firdaus \& Sjahruddin Issue 1 (Agustus, 2019); 01 15 


\section{JURNAL ORGANISASI DAN MANAJEMEN}

Issue 1 (Agustus, 2019)

https://doi.org/10.31227/osf.io/gcda8

Berdasarkan gambar diatas menunjukkan bahwa terdapat hubungan yang searah (linear) antara kompensasi dengan kepuasan kerja, hal ini ditunjukkan dengan garis linearitas yang dimunculkan pada gambar tersebut dengan nilai keofisien regresi linearitas sebesar 0.754 atau dengan tingkat linearitas sebesar 75.4\%.

\section{Hasil analisis}

\section{1) Analisis Statistik Deskriptif} berikut :

Hasil analisis statistic deskriptif pada tabel dapat dijelaskan sebagai

a) Kompensasi (X1), hasil penelitian ini menujukan nilai mean yaitu 3.7913 dan nilai standar deviasi yaitu 0.49193, dari hasil tesebut memberikan penjelasan nilai mean $>$ dari nilai standar deviasi sehingga dapat disimpulkan bahwa tingkat variabel kompensasi dalam penelitian ini baik digunakan sebagai representasi data.

b) Motivasi (X2), hasil penelitian ini menujukan nilai mean yaitu 3.7904 dan nilai standar deviasi yaitu 0.58151, dari hasil tesebut memberikan penjelasan nilai mean > dari nilai standar deviasi sehingga dapat disimpulkan bahwa tingkat variabel motivasi dalam penelitian ini baik digunakan sebagai representasi data.

c) Kepuasan Kerja (Y), hasil penelitian ini menujukan nilai mean yaitu 3.8534 dan nilai standar deviasi yaitu 0.51603, dari hasil tesebut memberikan penjelasan nilai mean $>$ dari nilai standar deviasi sehingga dapat disimpulkan bahwa tingkat variabel kepuasan kerja dalam penelitian ini baik digunakan sebagai representasi data.

\section{2) Analisis Statistik Inferensial}

Berdasarkan hasil pengolahan data dapat diketahui bahwa nilai koefisien regresi untuk variabel kompensasi (X1) terhadap kepuasan kerja (Y) sebesar 0.309 dan nilai keofisien regresi untuk variabel motivasi (X2) terhadap kepuasan kerja (Y) sebesar 0.622 sehingga didapatkan persamaan regresi sebagai berikut: $\mathrm{Y}=0.532+0.309+0.622$

Model ini telah menunjukkan bahwa kedua koefisien regresi bertanda positif memiliki arti, bahwa semakin tinggi kompensasi yang diperoleh pegawai dan motivasi kerja yang dicurahkan pegawai, maka semakin tinggi kepuasan kerja yang dirasakan pegawai. Dari pemaparan tersebut maka dapat dijelaskan bahwa keofisien kompensasi bertanda positif sebesar 0.309 yang berarti, apabila terjadi kenaikan sebesar 0,532 atau $53,20 \%$ pada variabel independen (kompensasi dan motivasi) maka variabel terikat akan meningkat sesuai dengan jumlah peningkatan yang sama pada variabel independen, hal yang sama jika sebaliknya.

\section{3) Koefisien determinasi $\left(R^{2}\right)$}

Berdasarkan hasil pengolahan data dapat diketahui $R$ Square sebesar 0.789. berdasarkan nilai $R$ Square ini dapat dikatakan bahwa 78.9\% variabel kepuasan kerja dapat dijelaskan oleh kompensasi dan 


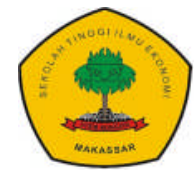

JURNAL ORGANISASI DAN MANAJEMEN

Issue 1 (Agustus, 2019)

https://doi.org/10.31227/osf.io/gcda8

motivasi, sedangkan kepuasan kerja yang tidak dapat dijelaskan oleh kompensasi dan motivasi dijelaskan oleh variable-variabel lain yang tidak diamati oleh peneliti adalah sebesar 21,1\% (100\%-78,9\%). Berdasarkan tabel diatas diketahui R sebesar 0.888. Berdasarkan nilai $\mathrm{R}$ ini dapat dikatakan bahwa sebesar $88.8 \%$ keeratan hubungan antara kompensasi, motivasi dan kepuasan kerja. Hubungan kompensasi, motivasi dan kepuasan kerja termasuk dalam keeratan hubungan yang kuat.

Berdasarkan tabel diatas dapat diketahui Adjusted R Square ini dapat sebesar 0.781. berdasarkan nilai Adjusted R Square ini dapat dikatakan bahwa kebaikan model untuk penelitian ini sebesar 78.1\%. dimana nilai $78.1 \%$ diatas 50\%, maka dpaat dikatakan bahawa model untuk penelitian ini adalah baik.

\section{4) Uji F (Model)}

Berdasarkan hasil pengolahan data menujukkan bahwa hasil pengujian model diperoleh nilai F-hitung (93.487) > F-tabel (3.182), sehingga hasil tersebut menujukkan bahwa data yang digunakan dalam penelitian ini dipandang sesuai (memenuhi kriteria model) bahwa nilai F-hitung > F-tabel.

\section{5) Uji Parsial (Uji-t)}

Berdasarkan hasil pengolahan data bahwa variabel kompensasi menujukkan t-hitung (2.872) > t-tabel (2.006) dan nilai signifikan sebesar $0.006<0.05$ maka $\mathrm{H}_{\mathrm{a}}$ diterima dan $\mathrm{H}_{0}$ ditolak. Dapat dikatakan bahwa kompensasi secara parsial berpengaruh positif dan signifikan terhadap kepuasan kerja pegawai, sehingga hipotesis dalam penelitian ini diterima.

Pada pengolahan data variabel motivasi menujukkan t-hitung (5.780) > t-tabel (2.006) dan nilai signifikan sebesar $0.000<0.05$ maka $\mathrm{H}_{\mathrm{a}}$ diterima dan $\mathrm{H}_{0}$ ditolak. Dapat dikatakan bahwa motivasi secara parsial berpengaruh positif dan signifikan terhadap kepuasan kerja pegawai, sehingga hipotesis dalam penelitian ini diterima.

\section{Rekomendasi Penelitian}

1. Berdasarkan hasil penelitian membuktikan bahwa variabel independen, yaitu Kompensasi $\left(\mathrm{X}_{1}\right)$ yang tinggi akan berpengaruh positif dan signifikan terhadap kepuasan kerja pegawai, sebaliknya kalau kompensasi yang rendah akan berpengaruh negatif dan tidak signifikan terhadap kepuasan kerja pegawai pada Kantor Balai Diklat Keagamaan Makassar, maka dinyatakan hipotesis pertama diterima.

2. Berdasarkan hasil penelitian membuktikan bahwa variabel independen, yaitu Motivasi $\left(\mathrm{X}_{2}\right)$, berpengaruh positif dan signifikan terhadap kepuasan kerja pegawai pada Kantor Balai Diklat Keagamaan Makassar (Y) maka dinyatakan hipotesis kedua juga diterima.

3. Berdasarkan hasil penelitian dapat ditarik kesimpulan bahwa variabel yang paling dominan berpengaruh terhadap Kepuasan kerja (Y) dari kedua 


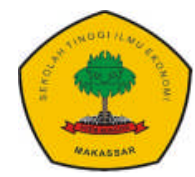

JURNAL ORGANISASI DAN MANAJEMEN

Issue 1 (Agustus, 2019)

https://doi.org/10.31227/osf.io/gcda8

variabel indenpenden adalah variabel Motivasi karena memiliki nilai kontribusi yang paling besar terhadap Kepuasan Kerja.

4. Bagi instansi, sebaiknya lebih meningkatkan motivasi yang diberikan kepada pegawainya lagi agar bisa terus mendorong pegawainya untuk lebih semangat bekerja serta tidak memberikan hasil yang negative untuk instansi dan juga bisa mengevaluasi hasil dari motivasi kerja yang diberikan untuk pegawai agar bisa mengetahui berapa besar pengaruh atau motivasi kerja terhadap kepuasan kerja pegawai sehingga pegawai bisa meningkatkan kinerja secara optimal dan efektif.

5. Bagi pegawai sebaiknya memperbaiki atau lebih memperhatikan lagi saat menyelesaikan pekerjaan yang diberikan oleh instansi dengan pegawai senatiasa mengevaluasi setiap pekerjaanya agar tingkat kesalahannya bisa diantisipasi pada pekerjaan selanjutnya.

6. Kompensasi berpengaruh positif dan signifikan terhadap kepuasan kerja pegawai, hal ini membuktikan bahwa kompensasi yang diberikan selama ini bisa memberikan kontribusi yang baik maka dari itu instansi harus lebih memperhatikan lagi kompensasi yang diberikan sedangkan motivasi berpengaruh positif dan signifikan terhadap kepuasan kerja pegawai, hal ini membuktikan bahwa dengan dorongan sebagai bentuk motivasi yang baik akan memberikan pengaruh yang tinggi pula terhadap kepuasan kerja pegawai. Maka dari itu pegawai sebaiknya bisa lebik baik lagi dalam menyelesaikan pekerjaanya sesuai dengan target yang telah ditentukan oleh instansi.

\section{Referensi}

Akhmad, J., (2013), Manajemen Sumber Daya Manusia, Jakarta : Lentera Ilmu Cendikia

Bangun, W., (2012), Manajemen Sumber Daya Manusia, Bandung : Erlangga.

Ghozali, Imam, (2011). "Aplikasi Analisis Multivariate Dengan Program SPSS", Semarang: Badan Penerbit Universitas Diponegoro.

Ghozali, Imam, (2013). Aplikasi Analisis Multivariate dengan Program IBM SPSS 21 Update PLS Regresi. Semarang:Badan Penerbit Universitas Diponegoro.

Hasibuan, Malayu S.P. (2011). Manajemen: Dasar, Pengertian, dan Masalah. Jakarta: PT. Aksara.

Hasibuan, Malayu S.P., (2013), Manajemen Sumber Daya Manusia, Cetakan Ketujuh belas, Jakarta : PT. Bumi Aksara

Hasibuan, Malayu S.P., (2013), Manajemen Sumber Daya Manusia, Cetakan Ketujuh belas, Jakarta : PT. Bumi Aksara.

Kasmir, Manajemen Sumber Daya Manusia (Teori dan Praktik)/Kasmir -Ed. 1.Cet.2.-Jakarta: Rajawali Pers, 2016.

Kadarisman. (2012). Manajemen Pengembangan Sumber Daya Manusia. Jakarta: PT. Rajagrafindo Persada.

La Edy dan Agustina Risambessy, (2018), pengaruh diklat, disiplin kerja dan kompetensi terhadap kinerja pegawai balai diklat kegamaan ambon, Pengaruh Diklat, Disiplin Kerja Dan Kompetensi Terhadap Kinerja Pegawai Balai Diklat Keagamaan Ambon, 6.

Pinder, Craig C. (2008). Work Motivation Organizational Behavior. New York: Psychology Press.

Halaman 12

Authors : Firdaus \& Sjahruddin Issue 1 (Agustus, 2019); 01 15 
Issue 1 (Agustus, 2019)

https://doi.org/10.31227/osf.io/gcda8

Sunyoto, D., (2012), Manajemen Sumber Daya Manusia, Jakarta : CAPS.

Siregar, Syofian. (2013). Metode Penelitian Kuantitatif. Dilengkapi perbandingan Perhitungan Manual \& SPSS. Edisi Pertama, Jakarta: Kencana.

Sinambela, Ljian Poltak. (2012). Kinerja Pegawai Teori Pengukuran dan Implikaso. Cetakan Pertama. Yogayakarta: Graha Ilmu.

Sugiyono. (2010). Metode Penelitian Pendidikan Pendekatan Kuantitatif, Kualitatif, dan R\&D. Bandung: Alfabeta

Sugiyono, (2013). Metode Penelitian Kuantitatif, Kualitatif dan R\&D. Bandung.

Sugiyono. (2013). Metode Penelitian Kuantitatif, Kualitatif dan R\&D. Bandung: Alfabeta. CV.

Sugiyono, (2014). Metode Penelitian Pendidikan Pendekatan Kuantitatif, Kualitatif, dan R\&D. Bandung: Alfabeta.

Siagian, Sondang P, (2015), Manajemen Sumber Daya Manusia.Jakarta : PT. Bumi Aksara.

Subekhi, Akhmad; dan Mohammad Jauhar. (2012). Pengantar MSDM. Jakarta: Prestasi Pustakaraya.

1. Variabel Kompensasi $\left(\mathrm{X}_{1}\right)$

Lampiran Kuesioner Penelitian

$\mathrm{X}_{1.1}$ Gaji

1. Besaran gaji yang saya terima sesuai dengan tanggung jawab saya terhadap pekerjaan.

2. Gaji yang saya terima dibayarkan secara tepat waktu

3. Gaji yang saya peroleh dinaikkan secara berkala sesuai dengan kenaikan pangkat, golongan dan jabatan saya.

$\mathrm{X}_{1.2}$ Insentif

1. Hasil kerja saya yang optimal dihargai oleh institusi dengan memberikan insentif yang wajar.

2. Insentif dalam bentuk finansial yang saya terima disesuaikan dengan kontribusi saya.

3. Institusi memberikan bonus ketika hasil kerja saya melampaui target.

$\mathrm{X}_{1.3}$ Fasiltas Kantor

1. Saya memanfaatkan fasilitas kantor dengan efektif

2. Saya menghindari penggunaan fasilitas kantor diluar jam kerja

3. Fasilitas kantor yang diberikan kepada saya, telah sesuai dengan kebutuhan pekerjaan saya.

$\mathrm{X}_{1.4}$ Tunjangan

1. Institusi melindungi keselamatan dan keamanan kerja saya melalui tunjangan kesehatan keselamatan kerja.

2. Untuk meringankan beban kerja pegawai institusi memberikan tunjangan cuti kepada pegawai.

3. Institusi menyediakan tunjangan hari tua pegawai ketika saya sudah pensiun.

\section{Variabel Motivasi $\left(\mathrm{X}_{2}\right)$}

\section{$\mathrm{X}_{2.1}$ Dorongan Mencapai Tujuan}

1. Dukungan keluarga memotivasi saya untuk menghasilkan pekerjaan yang sesuai dengan tujuan institusi.

2. Dukungan keluarga memotivasi saya untuk menghasilkan pekerjaan yang sesuai dengan tujuan institusi.

3. Saya adalah individu yang bersedia bekerja keras demi kemajuan institusi. 


\section{JURNAL ORGANISASI DAN MANAJEMEN}

Issue 1 (Agustus, 2019)

https://doi.org/10.31227/osf.io/gcda8

$\mathrm{X}_{2.2}$ Semangat Kerja

1. Saya sangat menyenangi pekerjaan yang diberikan kepada saya.

2. Saya senantiasa berupaya bekerja dengan penuh semangat.

3. Institusi senantiasa meningkatkan semangat kerja pegawai.

\section{$\mathrm{X}_{2.3}$ Inisiatif dan Kreatifitas}

1. Saya senantiasa berinisiatif melakukan pekerjaan dengan baik.

2. Saya senantiasa berkreatifitas dalam menjalankan pekerjaan yang menjadi tanggung jawab saya.

3. Saya senantiasa mencoba hal hal yang sifatnya baru dalam proses menyelesaikan pekerjaan saya.

$\mathrm{X}_{2.4}$ Tanggung Jawab

1. Saya bertanggung jawab penuh terhadap kekeliruan dan kesalahan yang saya lakukan dalam bekerja.

2. Saya bertanggung jawab sebatas beban kerja yang diberikan kepada saya.

3. Saya bertanggung jawab terhadap penggunaan anggaran dan fasilitas kerja yang saya gunakan dalam mendukung pekerjaan saya.

\section{Variabel Kepuasan Kerja (Y)}

$\mathrm{Y}_{1.1}$ Menyenangi pekerjaannya

1. Saya memiliki kesadaran yang tinggi dalam bekerja sehingga pekerjaan yang diberikan kepada saya, sangat saya senangi.

2. Saya akan tetap menyelesaikan pekerjaan saya walaupun pekerjaan tersebut sangat sulit.

3. Perhatian pimpinan dan rekan kerja menjadi alasan yang kuat sehingga saya menyenangi pekerjaan saya.

\section{$\mathrm{Y}_{1.2}$ Mencintai pekerjaannya}

1. Pekerjaan yang diberikan kepada saya sesuai dengan pengetahuan yang saya miliki.

2. Pekerjaan yang diberikan kepada saya sesuai dengan keahlian yang saya miliki.

3. Saya tetap akan bertahan pada pekerjaan saya sekalipun ada tawaran yang menarik untuk pekerjaan yang lainnya.

$\mathbf{Y}_{1.3}$ Moral Kerja

1. Saya bekerja sesuai dengan etika dan prosedural kerja yang berlaku.

2. Saya berani menyatakan tidak untuk hal hal yang tidak sesuai dengan procedural kerja yang berlaku.

3. Saya mampu membedakan pencapaian hasil kerja yang baik dan yang buruk.

$\mathbf{Y}_{1.4}$ Displin Kerja

1. Saya senantiasa hadir tetap waktu.

2. Saya senantiasa tunduk dan patuh terhadap perintah atasan.

3. Saya senantiasa menyelesaikan pekerjaan sesuai dengan waktu yang telah ditentukan.

Authors : Firdaus \& Sjahruddin Issue 1 (Agustus, 2019); 01 15 